\title{
Notes on Changes in Xosa resulting from contact with Europeans.
}

Language is an integral part of culture, and changes in life due to contact are reflected in language. The life of the Xosa-speaking people of South-East Africa has been greatly modified by contact with Europeans : Europeans have brought with them a new material culture, new institutions and functionaries, and new ideas. Each new thing absorbed has entailed a change in language.

Commonly the European (English or Afrikaans) word is adopted along with the thing

$\begin{array}{ll}\text { e.g. imela } & \text { a knife } \\ \text { ibulukwe a pair of trousers } \\ \text { ityali } & \text { a shawl1 } \\ \text { ikofu } & \text { coffee } \\ \text { imbotyi } & \text { beans } \\ \text { ivenlike } & \text { a store } \\ \text { idolopu } & \text { a town } \\ \text { intolongo a prison } \\ \text { irafu } & \text { tax } \\ \text { isikolo } & \text { a school } \\ \text { imantyi } & \text { a magistrate } \\ & \\ \text { ititshala } & \text { a teacher } \\ & \\ \text { iveki } & \text { a week } \\ \text { ukuwasa } & \text { to wash clothes }\end{array}$

Af. mes.

Af. broek.

Af. boontje.

Af. winkle.

Af. dorp.

Af. tronk.

Af. gaaf.

(umatyi when referring to a specific magistrate).

(utitshala when referring to a specific teacher).

ukuvasa to wash clothes

(as dist. from ukuhlamba, to wash the body).

Very many examples of this type may be cited. The European word adopted is not always the name of the person or thing, but may be a name connected in the native mind with it. A florin is known in Pondoland as iskotsman, because when Natal railways were being built a Scot in charge cheated labourers, who did not then recognize differences in European coins, by paying florins instead of half-crowns. Road labourers are known as amatiets, because a European foreman who was long in charge of roads in the early days, was a Mr. Tiets.

Sometimes no word is taken over with the object, but an onomatopoeic word is invented to describe it. Paraffin and petrol tins which are largely used for holding water, and which make peculiar gurgling noises when carried on women's heads, are called amagogogo. The noisy government bus is known in Pondoland as ibombela.

1 Except where otherwise stated the derivation is from the English word given as the translation. 
New words are made for new things from old roots, by the use of a class prefix not previously used with this root:

e.g. unobala

unodyebo

unocanda

umfundisi

umanyano

igqoboka a secretary

a treasurer

a surveyor

a minister

a church society

a Christian from ukubala

" indyebo

" ukucanda

" ukufundisa

" ukumanyana

" ukugqoboka to count.

a tich harvest.

to walk thro' fields.

to teach.

to join together.

to pierce through.

(idea that a person was converted by piercing through the heart).

Days of the week come into this class:

Ngomvulo Monday

Ngolwesibini Tuesday

Ngomgqibelo Saturday from ukuvula

" isibini

" ukugqiba to open.

the second.

to finish.

Existing words are used with new, or extended, meanings:

(a) They may retain their old meaning as well as acquiring a new one.

Word.

ukulima

ikaba

igumbi

umzuzana

iggira
Old Meaning.

to hoe for planting

a hoe

a corner

a short space of time

a diviner

New Meaning.

Many words for new colours or designs introduced with trade goods come under this category:

umsobo

umhobe

impangele nightshade with plumcoloured berry.

a dove

a guinea fowl

plum colour.

to plough.

a plough.

a room.

plur. minutes of a meeting.

a European doctor.

(b) A new content may replace the old:
imbiza
a clay cooking-pot
isitya
a beer basket
umitendeleko
a feast

a blue grey bead.

a dark print with small white dots.

In these the new content has replaced the old everywhere except in the most remote districts.

Besides these obviouschanges in the meanings of old words there are changes in shades of meaning, corresponding to changes in the culture. Inkosi (chief) does not convey to a town-bred native living under European administration, and owing only a vague hereditary allegiance to some chief, what it did to his fathers living in the time of great chiefs like Tshaka, Faku, and Hintsa. 
Ukulobola (to give bride-price) has changed in meaning with the changes in the custom.

Distinct from the borrowing, or creation of words to describe new objects, institutions, and ideas, is the absorption of European words and idioms referring to things already existing in the old culture. Forms of Afrikaans and English swear words have greatly increased the vocabulary of an angry Pondo who knows no European language. Kusebetela, a literal translation of the English idiom, it is better, is commonly used. Molo (pl. molveni) from Af. morgen, is a common form of greeting. Sometimes the introduced European word supplants the old Xosa word. European names for the months are so commonly used that in towns very few people know the Xosa names.

Certain European relationship terms have been widely adopted and in places have completely supplanted the old Xosa term. Usibali (Af. zwager) has so replaced the terms umlanya (sister's husband, wife's brother, wife's sister's husband) and umlanyakazi (wife's sister, wife's brother's wife) that I did not hear the latter terms until I had been inquiring for months on the subject. In towns and reserves in close contact with Europeans uauntie (Eng. auntie) and nompie (Af. oompie) are widely used. Uauntie is used for udadebobawo (father's sister), umakazi (mother's sister), and umkamalume (wife of mother's brother) and for any woman of the age of the speaker's mother, as a polite mode of address and reference. Usisi (Eng. sister) is used in place of udadewetu (sister) by both men and women, by women for an elder sister-in-law (indodakazi) and by both sexes as a polite mode of address to any woman of their own age. Ubootie (Af. boetjie) is used by women in place of umnakwetu (brother) for husband's brothers (umkuluwe and umninawe) and to any man of their own age. It is less generally used by men as for a younger brother (umninawe) (but not for an elder brother, umkuluwe) and as a term of address to equals in age.

These European words when absorbed assume much of the significance of the word which they replace. Uompie when used for ubawokazi conveys something of the reciprocal rights and duties between a boy and his father's brothers; when a woman uses ubootie to her husband's umkuluwe the whole pattern of respect and mutual avoidance is implied. But at the same time the new terms are a reflection of, and in themselves a means of producing a change in behaviour. The distinction in the mind of the child between father's sister and mother's sister is blurred when both are called wauntie. The tendency is to emphasize the fact that the mother is in a class by herself, and to lump these other female relations together. A similar process takes place when uompie is used for ubawokazi and umalume.

The interpretation of words in terms of the culture which has borrowed them is not confined to relationship terms alone. A crude example is that of iteameeti (tea meeting) which in Pondoland is now used for a disteputable type of beer-drink at which beer is sold, and which married women living 
with their husbands are not allowed to attend. With the word isporo (Af. $s p o k$ ) a new idea was introduced quite distinct from that. of itongo (ancestral spirit) or isitunzela (deceased raised by sorcery) but isporo has been interpreted in terms of native culture, and has many attributes which spoek did not have in Afrikaans culture. Ukwwakasha is used for the surprising new idea of going for a walk for walking's sake, but so strong is the old idea that a walker must have some objective that in remote districts when the word is used the inquirer assumes that the walker is going somewhere, but does not wish to state where. Urulumente (government) by the very fact of the use of a personal prefix shows that the European concept of government was not grasped by the native, and the government was thought of as a person. In some districts the idea of Urulumente as an old man with a white beard is still prevalent. Even with words like imantyi (magistrate) and ititshala (teacher) the concept conveyed to the native is not identical with the concept conveyed to the European by the European words from which they are derived.

To understand the content of the terms one is driven to an examination of their use in their original cultures, and of the conditions of contact. The Xosa borrowing of relationship terms from Afrikaans was conditioned by the fact that oompie and tante were widely used in Afrikaans not only as relationship terms but as modes of address to elders. The nature of the changes taking place are to be understood by a study of changes in other aspects of culture. The greatest culture change has been in the economic sphere and there is a correspondingly great change in the language of economics. The extent and rapidity of linguistic changes is explained by the revolutions in the way of life. Bantu are quick at picking up a new language, and many have been forced by economic necessity to learn something of English or Afrikaans. In towns conversation is interlarded with European words and phrases. The superior, social, and economic status of Europeans gives a reflected glory to those who can speak their language.

A marked feature of isiXosa is its adaptability. Examples have been given of new words made for new things from old roots. Many European words are successfully absorbed. Nouns are put into their appropriate classes, and the various forms of the verb made. Photography was a new phenomenon to some Pondo whom I visited, but very rapidly they adapted the English root and spoke of
ifoto
a photograph.
ukufotisa to take a photograph (causative form).
umfotokazi a female photographer.

From the Afrikaans word baas (master) the verb ukubasela, to act like a baas, i.e. to give a gift, has been derived. This flexibility of the language is its safeguard; in language the adaption to contact is more successful than in other aspects of culture. 
Besides the development of language to convey another culture, standardization is taking place due to the reduction of language to writing, and the increase in communication between districts. Differences in dialect tend to disappear. Pondo children use isiXosa school books and learn the Xosa words for things for which the word in the Pondo dialect is different:

$$
\begin{aligned}
& \text { e.g. Word. } \\
& \text { milk } \\
& \text { yesterday } \\
& \text { lion } \\
& \text { to hurry } \\
& \text { grandfather }
\end{aligned}
$$

Xosa.
ubisi
pezolo
ingonyama
ukubaleka
ubawomkulu

Pondo.

intusi.

izolo.

ibubesi.

ukugijima.

umakulu.

There are now many Fingo immigrants in Pondoland and they are having considerable influence on accent and vocabulary.

Some words are falling out of use. Words for old leather garments that have not changed in meaning, and been applied to garments of European manufacture, are disappearing, and town-bred men often do not know the fifty-odd words describing the marking of cattle.

With contact, therefore, there is development of language, and at the same time standardization and atrophy. (Communicated by Monica HuNTER.)

\section{The washing of the royal stool at Ho (Togoland)}

In May 1930 a new paramount chief ( fiaga ' King') was installed in Ho-Dome, after a long-continued quarrel about the ownership of the royal stool. At the ceremony of stool-washing representatives of the following towns were present: Akoefe, Sokode, Lume, Matse, Ayfoeta, Atikpui, Klefe, Hodzokofe, Dzodze-Akoviefe, apart from the paramount chief himself (who bears the title of Howusu) and his sub-chiefs of Axõe and Ahliha.

Since the 'stool-father' (the hereditary owner of the stool, who is not the king himself) Kpondo had stubbornly refused to surrender the royal stool, the elected king and his private councillors M. D. Kosi and A. Fia Yawo were obliged to make a new stool. The washing of this stool was the last and most important act of the coronation.

This was done on May 4th, 1931. The day for the ceremony must be a Monday following a market day which is a Sunday. About seven o'clock in the morning a number of priests and priestesses made their appearance. Two of them, Afadi, who is the priest of the stool, and Kayi, had to do the washing. They entered the house in which the stool was kept, holding in their hands a bowl which contained a mixture of water and gin into which some flour was strewn, and prayed: 'Honoured grandfather, we carry you to the river this morning to wash you according to the custom of our forefathers. Help us so that everything may succeed well, and bless us.' 